Brit. J. prev. soc. Med. (1976), 30, 203-212

\title{
Influence of family factors on the incidence of lower respiratory illness during the first year of life
}

\author{
S. R. LEEDER*, R. CORKHILL, L. M. IRWIG †, AND W. W. HOLLAND \\ Department of Community Medicine, St Thomas's Hospital Medical School, St Thomas's Hospital, London \\ J. R. T. COLLEY \\ Department of Community Health, Bristol
}

\begin{abstract}
Leeder, S. R., Corkhill, R., Irwig, L. M., Holland, W. W., and Colley, J. R. T. (1976). British Journal of Preventive and Social Medicine, 30, 203-212. Influence of family factors on the incidence of lower respiratory illness during the first year of life. In a study of a cohort of over 2000 children born between 1963 and 1965, the incidence of bronchitis and pneumonia during their first year of life was found to be associated with several family factors. The most important determinant of respiratory illness in these infants was an attack of bronchitis or pneumonia in a sibling. The age of these siblings, and their number, also contributed to this incidence. Parental respiratory symptoms, including persistent cough and phlegm, and asthma or wheezing, as well as parental smoking habits, had lesser but nevertheless important effects. Parental smoking, however, stands out from all other factors as the one most amenable to change in seeking to prevent bronchitis and pneumonia in infants.
\end{abstract}

This paper and the two that follow concern family factors that influence the incidence of respiratory illness and development of ventilatory function in children during the first five years of life.

Respiratory illnesses remain a major cause of death in infancy; the mortality rate for these diseases in infants in England and Wales has changed little since 1955 despite many new antibiotics. Viruses and allergies, rather than bacteria, are probably now responsible for many of the more serious respiratory illnesses in infancy (Colley, 1971; Glezen and Denny, 1973). As the management of viral and allergic illness is often difficult, there is good reason to seek ways in which these illnesses may be prevented. Prevention could also have other, longterm, benefits. Although clinical recovery from acute respiratory illness in childhood is usual, it may not always be as complete as has been assumed. In a number of studies, children with a history of lower respiratory tract illness have been found to have lower ventilatory function than children who escaped such illnesses (Wahdan, 1963; Lunn,

- Present address: Department of Medicine, McMaster University Medical Centre, Hamilton, Ontario, Canada L8S 4J9.

†Present address: National Research Institute for Occupational Diseases, P.O. Box 4788, Johannesburg 2000, Republic of South Africa.
Knowelden, and Handyside, 1967; Holland et al., 1969a; Colley and Reid, 1970; Bland, Holland, and Elliott, 1974). In a birth cohort followed-up until the age of 20 years, Colley, Douglas, and Reid (1973) found that those with a history of lower respiratory tract illness when under two years of age had a higher prevalence of respiratory symptoms at the age of 20 than those without this history. These findings are interpreted as evidence for some degree of permanent lung damage after childhood respiratory illness. Thus, prevention of acute lower respiratory illness in childhood may help to reduce respiratory morbidity in adult life.

Prevention of lower respiratory illness in infancy may be achieved in several ways. The opportunity for infection can be reduced by decreasing susceptibility through immunization, and by limiting contact of infants with others suffering from these illnesses. Complications may be reduced by more effective management of acute illness.

However, the most promising current approach must involve the modification of factors that are known to increase the risk of these illnesses. Parental smoking has been identified as one such factor (Colley, Holland, and Corkhill, 1974). While other factors have been identified as contributing 
to the incidence of respiratory disease in children, changes in them will often involve major environmental manipulation which may not be feasible. By contrast, parental smoking is potentially modifiable. Children of parents who smoke in the home have been found to have an increased risk of bronchitis and pneumonia in comparison with children of non-smoking parents. This is, in part, attributable to passive inhalation by infants of their parents' cigarette smoke.

In this paper we investigated a number of family factors to find out their influence on lower respiratory illness during the first year of life. In the next paper, factors influencing the incidence of wheezing and asthma during the first five years are considered. In the third paper, family factors influencing ventilatory function at the age of five years are examined.

\section{METHODS}

The methods described in this section apply to the following two papers also.

\section{Study SAMPLe}

A cohort of children born between 1963 and 1965 in Harrow, a residential suburb of north-west London, was followed-up for the first five years of life together with other members of their families. The sampling methods have been described (Colley and Holland, 1967; Holland et al., 1969b; Colley et al., 1974). All families living in six wards of the borough of Harrow who had an infant born to them between 1 July 1963 and 30 June 1965 were included in the study population, the only exclusions being families of infants who died within seven days of birth. A total of 2365 Harrow families were eligible for our study. However, of these
2365 families, 160 could not be visited or declined to participate, leaving $2205(93 \%)$ for investigatio (Table I).

The families were followed-up annually for five years, although it was not possible to assemble complete data on all individuals on all occasion? In the tables presented in this paper, the number $f$ subjects available for study is specified in footnotes and set out in detail in Table $I$.

\section{Enrolment Procedures}

Health visitors, specially trained as observer $\vec{\xi}$ for our study, visited infant (subsequently referreen to as the index child) and mother at home with $\overline{\text { in }}$ 14 days of the infant's birth, administered questionnaire to the parents, and measured the child's crown-rump length and chest circumference. The questionnaire sought among other items the birth weight of the infant and details of health birth. A one-in-three systematic sample of famities was then visited by a field team from St Thom î. Hospital. The field team readministered othe questionnaire used by the health visitors repeated the body measurements.

\section{Measurement of Ventilatory Function}

In addition to readministering the questionnaire the field team measured the ventilatory capacia of the infant using a portable pneumotacograph (Colley, 1965). Parents and other children in the family also had measurements of peak expiratof flow rates made, using the low-range Wright peak flow meter for the children and the adult range meter for the adults. All recordings using the peak flow meter were made with the subject seated. Five peak expiratory flow manoeuvres were recorded

TABLE I

HARROW STUDY POPULATION: NUMBERS OF INFANTS, MOTHERS, FATHERS, SIBLINGS, AND PARENT PAIRS BY YEAR OF STUDY

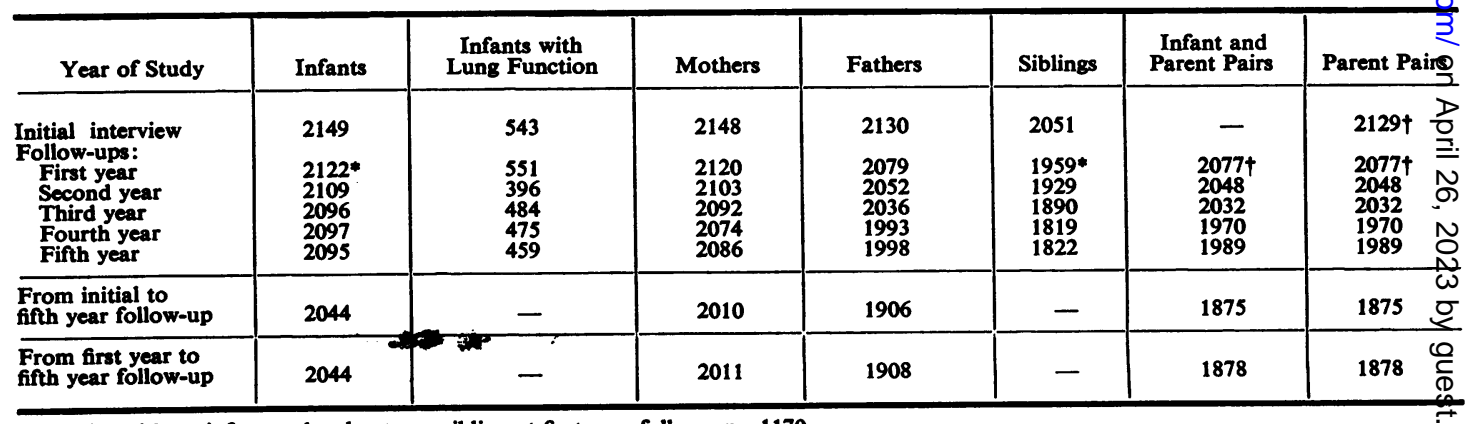


for each subject, the mean of the last three being used for analysis. The families in the one-in-three systematic sample were visited annually by members of the field team. Measurements of ventilatory function were made each year. Satisfactory records were not obtained from all subjects each year. Numbers of subjects with satisfactory records for analysis in the various tables are given in Table I, and elsewhere are indicated as footnotes. A comparison of the age, sex, and social class characteristics of these children and adults for whom ventilatory function data were available with those of the entire study sample revealed no important differences.

A total of 623 infants were eligible for measurement of lung function initially, of whom 487 had satisfactory records for all the five years. Measurements of ventilatory function were obtained in $\mathbf{4 6 0}$ mothers and 427 fathers when their children were aged five years.

\section{RESPIRATORY SYMPTOMS AND ILLNESSES}

At the initial interview the health visitor also obtained information concerning parents' smoking habits and respiratory symptoms.

Positive responses from parents to the question 'Do you usually cough first thing in the morning in the winter?' and/or 'Do you usually bring up phlegm from your chest first thing in the morning in winter?' were regarded as evidence of respiratory disability subsequently referred to as "coughphlegm'. Positive responses to the questions 'Does your chest ever sound wheezy or whistling?' and/or 'Have you ever had asthma?' were also regarded as evidence of respiratory disability termed 'asthma-wheeze'. At the initial examination and at the end of the first year of follow-up, parents were asked, 'Do you smoke?'. They were classified as smokers if they reported smoking both at the initial examination and at the end of the first year of follow-up, as non-smokers if they were smoking on neither occasion, and otherwise as changed smokers, see Table II. The validity of answers to these questions has already been established (Holland et al., 1969a). Social class was derived from the father's occupation using the Registrar General's classification (General Register Office Classification of Occupations, 1960).

\section{Follow-UP}

The families were followed-up annually for five years; the one-in-three sample was interviewed at the end of each year and the rest were followed-up with postal questionnaires. Information about the health of the family during the previous 12 months and on changes in parental occupation and smoking habits was obtained each year. If the father changed his occupation, social class for the year in which the change occurred was derived from his occupation at the beginning of that year. Parents were also asked about cough-phlegm and bronchitis or pneumonia in the siblings of index infants and in the index infants themselves using the questions, 'Has he or she had, in the past 12 months, bronchitis? pneumonia? bad colds? whooping cough?'. The parents' accounts of these illnesses were checked, in a sample, by examining general practitioners' records and the level of agreement between the parental and medical data was adequate (Colley et al., 1974). At the end of the third and subsequent years, parents were asked of their children, 'Has he or she ever had asthma?' and "Does his or her chest ever sound "wheezy", "chesty" or "whistling"?'. In the fourth and fifth years this question was modified by the parenthesis, 'other than when he or she has a cold'. Parents were also asked to name all illnesses they could recall their child having suffered during the

TABLE II

DEFINITION OF CATEGORIES USED TO TABULATE PARENTAL SMOKING HABITS

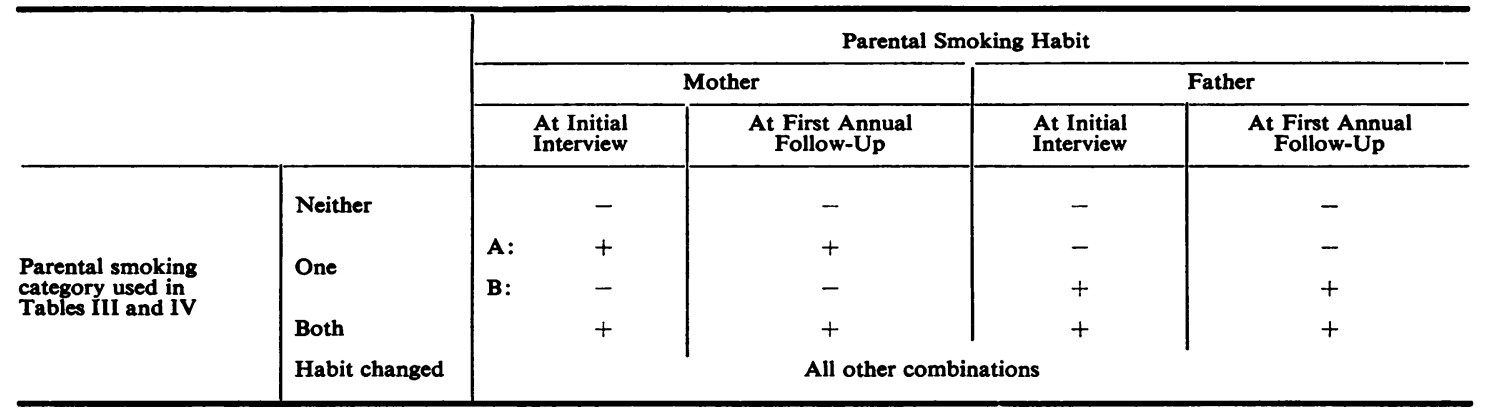


previous year, whether these had led to hospital admission, medical consultation, or no action.

Parents were also asked each year about coughphlegm which they may have suffered themselves during the previous 12 months. In the following analyses, the influence of parental cough-phlegm on respiratory illness in children has been studied over different periods. Children were classified according to prevalence of parental cough-phlegm reported at the end of the first year of life of the index child, see Tables IV, $V$, and VIII. In Table $X$ children were classified according to parental cough-phlegm prevalence at both the beginning and end of the first year. Consequently the number of children whose parents had no cough-phlegm in this classification was less (1286) than if prevalence of cough-phlegm at the end of the first year was considered alone (1498).

In the next paper 'Influence of family factors on asthma and wheezing during the first five years of life' (pages 213-218), parental cough-phlegm was considered during the full five-year period and not simply in the first year. The effect of change in parental cough-phlegm prevalence during these five years was also studied. Consequently, in Tables IV and $V$ of that paper, parental cough-phlegm refers to the entire five-year period. The numbers in all these tables are further modified by availability of data for other classification variables (such as parental smoking habits in Table IV of this paper) as explained in the footnotes to the tables.

\section{RESULTS}

During the first year of life, the incidence of bronchitis and pneumonia varied according to several family factors. These illnesses occurred much more commonly in infants born to families which had several other children already, and in? those families where the parents had respiratory disability or were smokers.

Children whose parents both had a history of asthma-wheeze had an incidence of bronchitis otํㅡㄹ pneumonia of $26.9 \%$ which was three times greater than that found in children of parents? without such a history $(9.4 \%)$ (Table III). Thes effect of parental smoking was not so great. The incidence of bronchitis or pneumonia in childrenof non-smoking parents was $7 \cdot 2 \%$ compared withw $17 \cdot 7 \%$ when both parents smoked. When both smoking habits and asthma-wheeze were examinedf for combined effects on the incidence of bronchitisw or pneumonia in the children, these contrasts widened. For example, the incidence of bronchitis or pneumonia was $6.7 \%$ in infants whose parents neither smoked nor had suffered from asthma응 wheeze; this contrasted with an incidence of $39.30 \%$ when both parents smoked and had a history asthma-wheeze.

Parental cough-phlegm, like asthma-wheeze 3 was associated with a higher incidence of bronchitis or pneumonia in the children (Table IV). Childogent whose parents did not give this history had anN incidence of bronchitis or pneumonia of 9. compared with $26 \cdot 3 \%$ of those whose parents both had this symptom. However these associations while strong, were not wholly consistent. Incidence of bronchitis or pneumonia did not always increase in line with presence of symptoms in parents, as seer? in the case of the combined influence of thes $\overrightarrow{\vec{E}}$ symptoms and parental smoking habits. This may in part be a consequence of these rates being based upon small numbers.

TABLE III

ANNUAL INCIDENCE PER 100 INFANTS OF BRONCHITIS OR PNEUMONIA IN THE FIRST YEAR OF LIFE BY PARENTA HISTORY OF ASTHMA-WHEEZE AND SMOKING HABIT

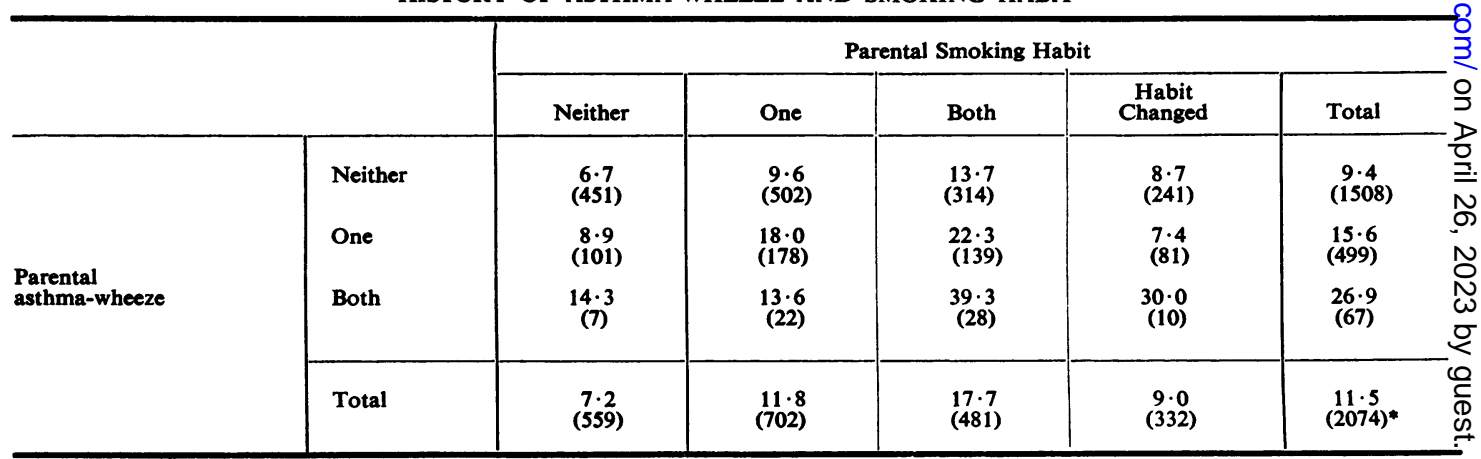


TABLE IV

ANNUAL INCIDENCE PER 100 INFANTS OF BRONCHITIS OR PNEUMONIA IN THE FIRST YEAR OF LIFE BY PARENTAL HISTORY OF COUGH-PHLEGM AND SMOKING HABIT

\begin{tabular}{|c|c|c|c|c|c|c|}
\hline & & \multicolumn{5}{|c|}{ Parental Smoking Habit } \\
\hline & & Neither & One & Both & $\underset{\text { Changed }}{\text { Habit }}$ & Total \\
\hline \multirow{4}{*}{$\begin{array}{l}\text { Parental } \\
\text { cough-phlegm }\end{array}$} & Neither & $\begin{array}{c}7 \cdot 6 \\
(490)\end{array}$ & $\begin{array}{r}10 \cdot 8 \\
(474)\end{array}$ & $\begin{array}{r}13 \cdot 8 \\
(290)\end{array}$ & $\begin{array}{c}6 \cdot 2 \\
(244)\end{array}$ & $\begin{array}{c}9 \cdot 5 \\
(1498)\end{array}$ \\
\hline & One & $\begin{array}{r}3 \cdot 3 \\
(61)\end{array}$ & $\begin{array}{l}10 \cdot 1 \\
(199)\end{array}$ & $\begin{array}{l}25 \cdot 4 \\
(142)\end{array}$ & $\begin{array}{l}15 \cdot 2 \\
(79)\end{array}$ & $\begin{array}{l}14 \cdot 6 \\
(481)\end{array}$ \\
\hline & Both & $\begin{array}{c}12 \cdot 5 \\
(8)\end{array}$ & $\begin{array}{r}14.4 \\
(29)\end{array}$ & $\begin{array}{r}18 \cdot 4 \\
(49)\end{array}$ & $\begin{array}{c}33 \cdot 3 \\
(9)\end{array}$ & $\begin{array}{r}26 \cdot 3 \\
(95)\end{array}$ \\
\hline & Total & $\begin{array}{c}7 \cdot 2 \\
(559)\end{array}$ & $\begin{array}{l}11 \cdot 8 \\
(702)\end{array}$ & $\begin{array}{l}17 \cdot 7 \\
(481)\end{array}$ & $\begin{array}{c}9 \cdot 0 \\
(332)\end{array}$ & $\frac{11 \cdot 5}{(2074) *}$ \\
\hline
\end{tabular}

Populations in parentheses

* Total excludes 27 infants with missing first year data and an additional 48 with missing initial and first year data on parent pairs.

TABLE V

ANNUAL INCIDENCE PER 100 INFANTS OF BRONCHITIS OR PNEUMONIA IN THE FIRST YEAR OF LIFE BY PARENTAL HISTORY OF COUGH-PHLEGM AND ASTHMA-WHEEZE

\begin{tabular}{|c|c|c|c|c|c|}
\hline & & \multicolumn{4}{|c|}{ Parental Cough-Phlegm } \\
\hline & & Neither & One & Both & Total \\
\hline \multirow{4}{*}{$\begin{array}{l}\text { Parental } \\
\text { asthma-wheeze }\end{array}$} & Neither & $\begin{array}{c}8 \cdot 7 \\
(1174)\end{array}$ & $\begin{array}{l}10 \cdot 4 \\
(288)\end{array}$ & $\begin{array}{r}21 \cdot 7 \\
(46)\end{array}$ & $\begin{array}{c}9.4 \\
(1508)\end{array}$ \\
\hline & One & $\begin{array}{l}12 \cdot 1 \\
(298)\end{array}$ & $\begin{array}{l}19 \cdot 4 \\
(165)\end{array}$ & $\begin{array}{r}27 \cdot 8 \\
(36)\end{array}$ & $\begin{array}{l}15.6 \\
\text { (499) }\end{array}$ \\
\hline & Both & $\begin{array}{r}19 \cdot 2 \\
(26)\end{array}$ & $\begin{array}{r}28.6 \\
(28)\end{array}$ & $\begin{array}{l}38 \cdot 5 \\
(13)\end{array}$ & $\begin{array}{r}26 \cdot 9 \\
(67)\end{array}$ \\
\hline & Total & $\begin{array}{c}9 \cdot 5 \\
(1498)\end{array}$ & $\begin{array}{l}14 \cdot 6 \\
(481)\end{array}$ & $\begin{array}{r}26 \cdot 3 \\
(95)\end{array}$ & $\begin{array}{l}11 \cdot 5 \\
(2074)^{*}\end{array}$ \\
\hline
\end{tabular}

Populations in parentheses

*Total excludes 27 infants with missing first year data and an additional 48 with missing initial and first year data on parent pairs.

TABLE VI

ANNUAL INCIDENCE PER 100 INFANTS OF BRONCHITIS OR PNEUMONIA IN THE FIRST YEAR OF LIFE BY NUMBER OF SIBLINGS AND THEIR HISTORY OF BRONCHITIS OR PNEUMONIA DURING THAT YEAR

\begin{tabular}{|c|c|c|c|c|c|c|}
\hline & & \multicolumn{5}{|c|}{ Number of Siblings } \\
\hline & & 0 & 1 & 2 & 3 or More & Total \\
\hline \multirow{3}{*}{$\begin{array}{l}\text { Bronchitis or pneumonia } \\
\text { in siblings during first } \\
\text { year of life of index infants }\end{array}$} & None & $\begin{array}{c}7.4 \\
(925)\end{array}$ & $\begin{array}{l}10 \cdot 0 \\
(641)\end{array}$ & $\begin{array}{l}12 \cdot 3 \\
(268)\end{array}$ & $\begin{array}{l}17 \cdot 8 \\
(146)\end{array}$ & $\begin{array}{c}9 \cdot 8 \\
(1980)\end{array}$ \\
\hline & $\begin{array}{l}\text { One or more } \\
\text { episodes }\end{array}$ & - & $\begin{array}{r}40 \cdot 7 \\
(54)\end{array}$ & $\begin{array}{r}37.0 \\
(27)\end{array}$ & $\begin{array}{r}35 \cdot 3 \\
(34)\end{array}$ & $\begin{array}{l}38 \cdot 2 \\
(115)\end{array}$ \\
\hline & Total & $\begin{array}{l}7.4 \\
(925)\end{array}$ & $\begin{array}{l}12 \cdot 4 \\
(695)\end{array}$ & $\begin{array}{l}14 \cdot 6 \\
(295)\end{array}$ & $\begin{array}{c}21 \cdot 1 \\
(180)\end{array}$ & $\begin{array}{l}11 \cdot 4 \\
(2095)\end{array}$ \\
\hline
\end{tabular}


Children of parents with a history of both asthma-wheeze and cough-phlegm had a higher incidence of bronchitis and pneumonia in the first year than did children whose parents had one or other but not both of these symptoms (Table V).

The incidence of bronchitis and pneumonia in the index infants was closely associated with both the number of siblings in the family and their respiratory history (Table VI). The most important items of respiratory history were attacks of bronchitis or pneumonia in a sibling during the first year of life of the index infant. When this occurred the overall incidence was $38.2 \%$. This contrasted with an incidence of $7.4 \%$ in the 925 infants who had no siblings.

There was also an association between the age of the siblings and incidence of bronchitis and pneumonia in the index infants. This was most obvious in relation to the eldest sibling-that is, the first child in each family, as shown in the top row of Table VII. There was a steady increase in incidence of illness with increasing age of the eldest sibling, being lowest when the eldest sibling was under three years and highest when the eldest sibling was aged five, and thus likely to be starting school. If the eldest sibling was over five years old the trend with age reversed; the incidence of illness in index infants was lower the older the sibling. When all siblings were considered together irrespective of their position in the family (bottom row Table VII), a similar relationship was found between mean age and incidence of illness in the index infants.

Factors such as ambient air pollution and low socioeconomic class have been shown to be important in the development of respiratory symptoms and illnesses in other groups of children (Holland et al., 1969b; Colley and Reid, 1970).

However, no variation in illness incidence was found in the children in this study during the first year of life 3 which could be attributed to the influence of socialo and physical environmental factors. The different $\vec{F}$ areas in which the children lived showed little variation in general environment and air pollution? at the time the index children were born, although $\bar{c}$. there had been differences in pollution levels not $\frac{\text { p }}{\sigma}$ many years before. This previous difference may explain the variation found in the incidence of $w$ respiratory illness among the older siblings in this $\vec{\circ}$ sample (Colley and Holland, 1967) living indifferent areas of Harrow.

Bronchitis and pneumonia in the siblings was also? associated with a history of cough-phlegm in theo parents as seen in Table VIII. This association wasiw independent of family size, and was present in ${ }_{+}^{\circ}$ families with one, two, three, or more siblings. in A similar relationship was found between siblinge bronchitis and pneumonia and parental asthma-o wheeze (Table IX).

Examination of the data thus far presented dind not suggest any multiplicative interaction betwe क्षूत the various factors associated with bronchitis 3 and pneumonia in the index infants. However, because some of the factors were themsells: interrelated (for example, parental cough-phlegin and smoking), it was difficult to assess the influeno. of each individual factor upon the incidence :ofo respiratory illness in the children. By fitting as logistic model to the data, with the incidence of bronchitis and pneumonia in the index children aso the outcome variable, this aspect was investigated $\mathbb{Q}$ further. The independent variables included in the $\overrightarrow{0}$ model were parental smoking, parental cough- 3 phlegm (considered at several levels depending? upon its presence in parents at both the beginning

TABLE VII

ANNUAL INCIDENCE PER 100 INFANTS OF BRONCHITIS OR PNEUMONIA DURING THE FIRST YEAR OF LIFE BY AGE (YEARS) OF SIBLINGS AND THEIR POSITION IN THE FAMILY

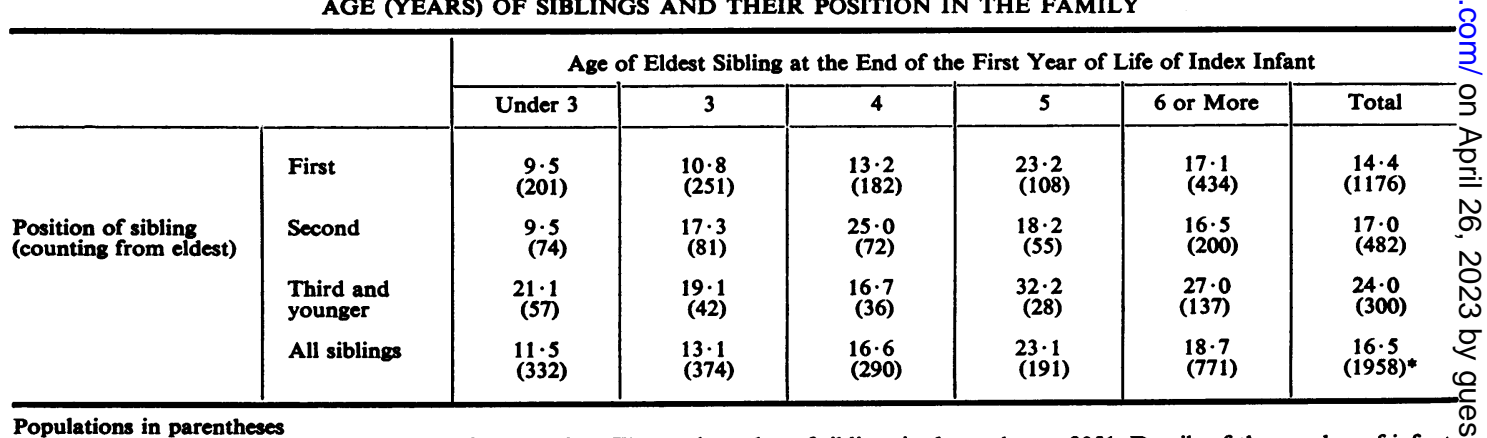


TABLE VIII

ANNUAL INCIDENCE PER 100 FAMILIES OF BRONCHITIS OR PNEUMONIA IN ANY SIBLINGS OF THE INDEX INFANTS BY NUMBER OF SIBLINGS AND PARENTAL HISTORY OF COUGH-PHLEGM

\begin{tabular}{|c|c|c|c|c|c|}
\hline & & \multicolumn{4}{|c|}{ Number of Siblings } \\
\hline & & 1 & 2 & 3 or More & Total \\
\hline \multirow{4}{*}{$\begin{array}{l}\text { Parental } \\
\text { cough-phlegm }\end{array}$} & Neither & $\begin{array}{l}6 \cdot 7 \\
(492)\end{array}$ & $\begin{array}{l}7.8 \\
(192)\end{array}$ & $\begin{array}{c}16 \cdot 3 \\
(98)\end{array}$ & $\begin{array}{c}8 \cdot 2 \\
(782)\end{array}$ \\
\hline & & $\begin{array}{l}10 \cdot 1 \\
(158)\end{array}$ & $\begin{array}{r}11.4 \\
(79)\end{array}$ & $\begin{array}{r}17 \cdot 5 \\
(63)\end{array}$ & $\begin{array}{l}12 \cdot 0 \\
(300)\end{array}$ \\
\hline & Both & $\begin{array}{r}17 \cdot 2 \\
(29)\end{array}$ & $\begin{array}{l}13 \cdot 0 \\
(23)\end{array}$ & $\begin{array}{r}43 \cdot 8 \\
(16)\end{array}$ & $\begin{array}{r}22 \cdot 1 \\
(68)\end{array}$ \\
\hline & Total & $\begin{array}{l}8 \cdot 0 \\
(679)\end{array}$ & $\begin{array}{c}9 \cdot 2 \\
(294)\end{array}$ & $\begin{array}{l}19 \cdot 2 \\
(177)\end{array}$ & $\begin{array}{l}10 \cdot 0 \\
\text { (1150)* }\end{array}$ \\
\hline
\end{tabular}

Populations in parentheses

* Total excludes 27 infants with missing first year data; 925 infants with first year data available but who had no siblings; 27 with a sibling but for whom first year data were missing; and 20 families with missing first year data on parent pairs.

TABLE IX

ANNUAL INCIDENCE PER 100 FAMILIES OF BRONCHITIS OR PNEUMONIA IN ANY SIBLINGS OF THE INDEX INFANTS BY NUMBER OF SIBLINGS AND PARENTAL HISTORY OF ASTHMA-WHEEZE

\begin{tabular}{|c|c|c|c|c|c|}
\hline & & \multicolumn{4}{|c|}{ Number of Siblings } \\
\hline & & 1 & 2 & 3 or More & Total \\
\hline \multirow{4}{*}{$\begin{array}{l}\text { Patental } \\
\text { asthma-wheeze }\end{array}$} & Neither & $\begin{array}{c}7.9 \\
(518)\end{array}$ & $\begin{array}{c}7.7 \\
(195)\end{array}$ & $\begin{array}{l}13.5 \\
\text { (119) }\end{array}$ & $\begin{array}{l}8.7 \\
\text { (832) }\end{array}$ \\
\hline & One & $\begin{array}{l}6.4 \\
\text { (156) }\end{array}$ & $\begin{array}{c}10.2 \\
(88)\end{array}$ & $\begin{array}{r}29 \cdot 4 \\
(51)\end{array}$ & $\begin{array}{l}11 \cdot 5 \\
\text { (295) }\end{array}$ \\
\hline & Both & $\begin{array}{r}18.8 \\
(16)\end{array}$ & $\begin{array}{r}27 \cdot 3 \\
(11)\end{array}$ & $\begin{array}{c}33 \cdot 3 \\
(9)\end{array}$ & $\begin{array}{r}25.0 \\
(36)\end{array}$ \\
\hline & Total & $\begin{array}{c}7.8 \\
(690)\end{array}$ & $\begin{array}{c}9 \cdot 2 \\
(294)\end{array}$ & $\begin{array}{l}19 \cdot 0 \\
(179)\end{array}$ & (1163)* \\
\hline
\end{tabular}

Populations in parentheses

*Total excludes 27 infants with missing first year data; 925 infants with first year data available but who had no siblings; 27 with a sibling but for whom first year data were missing; and seven families with missing intial data on parent pairs.

and the end of the first year), parental asthma-wheeze, number of siblings, sibling bronchitis or pneumonia, sibling cough-phlegm, sex of child, social class of father, and areas of residence. Several factors, notably social class, residential area, and sibling cough-phlegm made no significant contribution to the model which was then refitted without these variables. The results from this second model are presented in Table $\mathbf{X}$. Bronchitis and pneumonia in siblings was found to have the largest effect upon the adjusted incidence rates of bronchitis and pneumonia in the index infants; the adjusted incidence rate was $8.6 \%$ in the absence of this factor and $47.6 \%$ when two or more siblings had these illnesses. Parental smoking had the next largest effect and parental asthma-wheeze had a lesser, but significant, effect in the model.
Crude incidence rates suggested a strong relationship between parental cough-phlegm and illness in the index infants. The influence of parental cough-phlegm was strongest when parents reported that they had suffered from cough-phlegm both at the time of the initial interview and when interviewed again one year later. Thus among children of parents who reported cough-phlegm on the two occasions, $42.1 \%$ (that is eight out of 19) suffered from bronchitis or pneumonia compared with only $9.0 \%$ (that is, 116 out of 1286) in children whose parents were free of cough-phlegm initially and at the end of the first year. However, when adjustment had been made for other factors in the model, the effect of parental cough-phlegm was no longer statistically significant. 
TABLE X

CRUDE AND ADJUSTED INCIDENCE RATES PER 100 INFANTS FOR BRONCHITIS OR PNEUMONIA FOR LEVELS OF EACH FACTOR WITH ESTIMATES OF THEIR EFFECTS

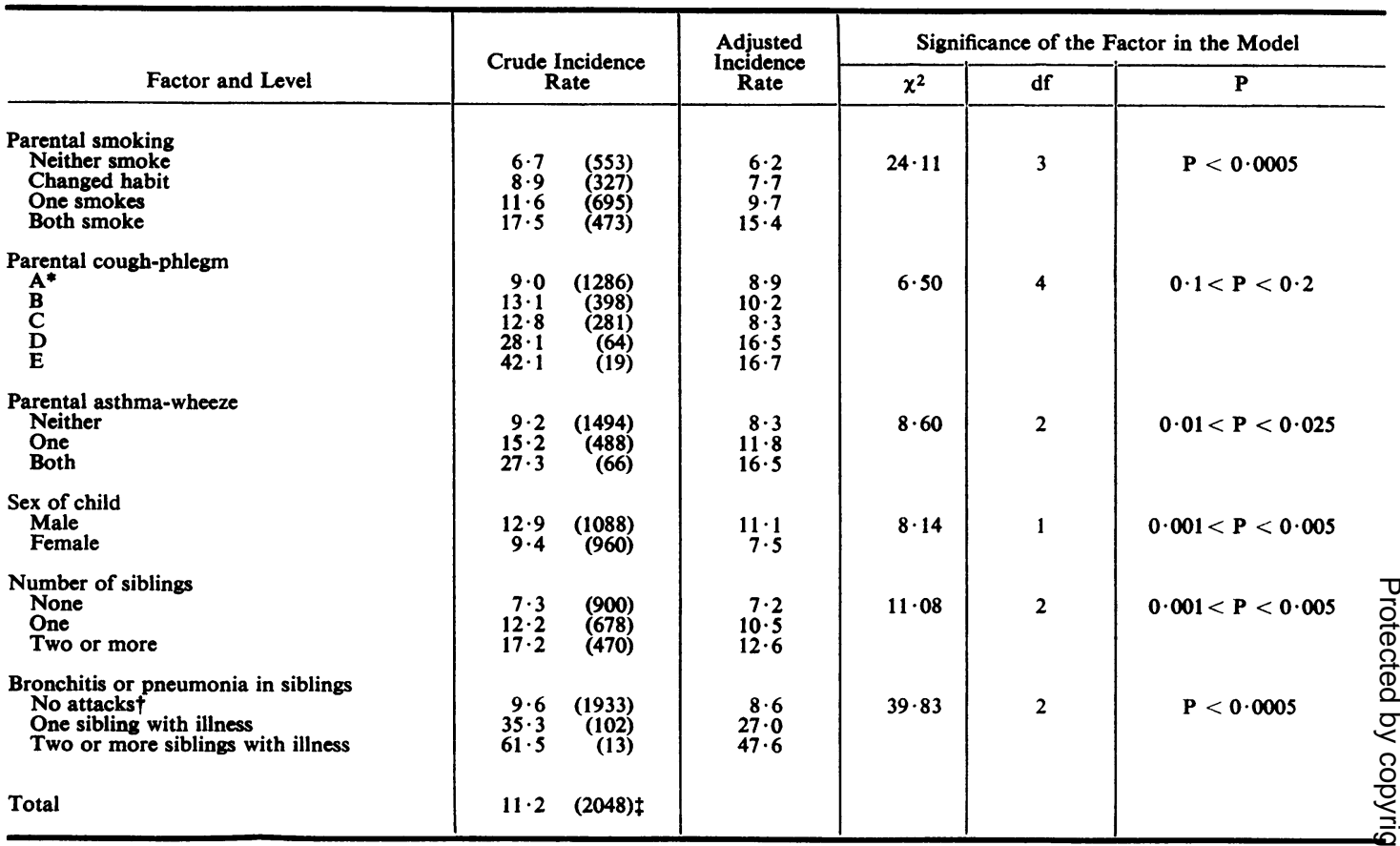

*A-neither parent ever had cough-phlegm; B-one parent had it either at the beginning or end of the first year of life of index child C-both parents had it once or one parent had it twice; D-one parent had it once, and the other twice: E-both parents had it twice.

ti.e. either no siblings, or if siblings, then they had no illness.

† Total excludes 27 families with infants with missing first year data; an additional 27 families with siblings with missing first year data, and 47 families with missing initial or first year data on parent pairs.

Populations in parentheses

There was a sex difference in the incidence of bronchitis and pneumonia in the children; the adjusted overall incidence for boys being $11 \cdot 1 \%$ compared with $7 \cdot 5 \%$ for girls.

To determine whether these factors were specifically related only to a history of lower respiratory illness in the index infants their association with upper respiratory illnesses was also examined using a logistic model. Here the outcome variable was the incidence of 'bad colds' in the first year. In this model, only parental cough-phlegm and sibling bronchitis or pneumonia were statistically significant factors $(P<0.001$ in each case) but parental smoking and asthma-wheeze were not. The overall association between bad colds and these family factors was considerably weaker than was their association with bronchitis or pneumonia.

\section{Discussion}

The present study has been concerned with attempting to identify and separate the various family factors influencing the incidence of acute lower respiratory illness in children during their first year of life. Colley et al. (1974) have already shown that both smoking and phlegm production by parents contribute to the incidence of respiratory disease in these children. This paper extends the investigation and demonstrates the additional influence of a parental history of asthma-wheeze, and the importance of both the number of siblings and their history of respiratory disease.

Parental asthma-wheeze was found to be associated with respiratory illness in the index infants in a different way to that seen for parental cough-phlegm. Parental asthma-wheeze appears to exert its influence independent of the number, age, $N$ or respiratory illness history of the siblings. This contrasted with parental cough-phlegm, where $\tilde{O}$ these factors did appear to have an influence both $N$ on infant respiratory illness and the parental $\underset{2}{\sigma}$ symptoms themselves.

A further difference between the effects of parental cough-phlegm and asthma-wheeze was apparent when the incidence of bad colds was 
examined in relation to the factors shown to be important in the incidence of bronchitis and pneumonia. Parental cough-phlegm was associated with an increased risk of bad colds in the index infants, whereas parental asthma-wheeze was without effect. Taken together these observations suggest that genetic factors may be more important in explaining the association between parental asthma-wheeze and bronchitis and pneumonia in the children than they are in the case of parental cough-phlegm. Here an environmental factor which is intimately related to parental smoking habits and sibling respiratory illness history is probably implicated.

Sibling bronchitis or pneumonia, parental coughphlegm, parental asthma-wheeze and bronchitis or pneumonia in the index infants were all closely associated in this study. The analysis using a logistic model suggested that sibling illness had the greatest effect although this must be interpreted within the limitations implicit in the use of the model. Without further information about the time sequence of illness in parents, siblings, and index infants it is not possible to decide exactly how cause and effect should be imputed in this situation. The finding that sibling illness appeared to be the most important factor is consistent with other family studies where siblings have been found to serve as primary cases in family epidemics of respiratory illness (Brimblecombe et al., 1958; Dingle, 1973; Williams, 1975). That the association between sibling illnesses and illness in the index infants was strongest when the siblings were of school starting age makes cross-infection from the siblings a likely circumstance as this age is known to be one of high incidence of respiratory illness (Reid, 1969).

The association of parental asthma-wheeze with bronchitis and pneumonia in the first year of life raises the possibility that some episodes of 'bronchitis' or 'pneumonia' were really episodes of asthma. We examined this question by noting the subsequent course of children with respect to asthma at ages three, four, and five years. Some children of parents with asthma-wheeze subsequently developed asthma themselves. Other children of parents with the same history did not develop asthma. These two groups of children had a similar incidence of bronchitis and pneumonia in the first year of life. Assuming equal exposure and susceptibility to respiratory pathogens in these two groups of children (that is those who subsequently developed asthma and those who did not), there is thus no evidence in this study to suggest that parents with asthma-wheeze tended to call asthmatic attacks in their children 'bronchitis' or 'pneumonia'.

In this study, cigarette smoking by parents stands out from all the other factors associated with bronchitis and pneumonia in young children, as the one most amenable to change. There seems to be good reason for actively bringing to the notice of smoking parents the dangers this habit carries for their young children.

This study was supported in part by the Department of Health and Social Security. Dr S. R. Leeder was in receipt of a National Health and Medical Research Council (Australia) Clinical Sciences Fellowship. It was undertaken in conjunction with the London Borough of Harrow Health, Welfare, and Children's Department. We should particularly like to thank Miss I. Watson and Miss M. S. Hirschhorn, Superintendent Health Visitors, and their staff, and Mr G. Phipps, Senior Administrative Assistant in the Personnel Health Section and his staff, and all other individuals who took part for their help and co-operation.

We thank Miss C. Astbury, Miss S. Brenner, Miss P. Cox, Miss J. Dale, Miss H. Polak, and Miss A. Witts for maintaining the records and doing most of the field work, Mr Andy Thomson for his help with data processing, and Mrs Susie Gilderdale and Miss Bridget McClune for their assistance in the preparation of this paper.

Requests for reprints: R. Corkhill, Lecturer in Medical Statistics, Department of Community Medicine, St Thomas's Hospital Medical School, London SE1 7EH.

\section{REFERENCES}

Bland, J. M., Holland, W. W., and Elliott, A. (1974). The development of respiratory symptoms in a cohort of Kent schoolchildren. Bull. physiopathol. Resp., 10, 699.

Brimblecombe, F. S. W., Cruickshank, R., Masters, P. L., Reid, D. D., Stewart, G. T., and Sanderson, D. (1958). Family studies of respiratory infections. Brit. med. J., 1, 119.

Colley, J. R. T. (1965). Method for measuring lung function in babies suitable for the epidemiologist. J. Physiol. (Lond.), 177, 40p.

(1971). Respiratory disease in childhood. Brit. med. Bull., 27, 9.

- Douglas, J. W. B., and ReID, D. D. (1973). Respiratory disease in young adults: influence of early childhood respiratory tract illness, social class, air pollution and smoking. Brit. med. J., 3, 195.

- and Holland, W. W. (1967). Social and environmental factors in respiratory disease. Arch. environm. Hlth, 14, 157. 
Holland, W. W., and Corkhill, R. T. (1974). Influence of passive smoking and parental phlegm on pneumonia and bronchitis in early childhood. Lancet, 2, 1031.

and REID, D. D. (1970). Urban and social origins of childhood bronchitis in England and Wales. Brit. med. J., 2, 213.

Dingle, J. H. (1973). The ills of man. Scientific American, 229, 77.

General Register Office Classification of OccupaTIONs (1960). Her Majesty's Stationery Office, London.

Glezen, W. P. and Denny, F. W. (1973). Epidemiology of acute lower respiratory disease in children. New Engl. J. Med., 288, 498.

Holland, W. W., Halil, T., Bennett, A. E., and Elliort, A. (1969a). Factors influencing the onset of chronic respiratory disease. Brit. med. J., 2, 205.
Holland, W. W., Kasap, H. S., Colley, J. R. T., and CORMACK, W. (1969b). Respiratory symptoms and ventilatory function: a family study. Brit. J. prev. soc. Med., 23, 77.

LunN, J. E., KNowelden, J., and Handyside, A. J. (1967). Patterns of respiratory illness in Sheffield infant schoolchildren. Brit. J. prev. soc. Med., 21, 7.

REID, D. D. (1969). The beginnings of bronchitis. Proc. roy. Soc. Med., 62, 311.

Wahdan, M. H. M. E-H. (1963). Atmospheric pollution and other environmental factors in respiratory disease of children. PhD thesis, University of London.

Williams, S. (1975). Children are a common source of respiratory infection for adults. Med. J. Aust., 1, 309. 